\title{
The Influence of Adopting Widescreen Televisions on Egyptian Au- dience's Viewing Practice
}

\author{
By Mustafa Mahmoud Yousry \\ Spring 2014 Issue of KINEMA \\ WIDESCREEN TELEVISION IN THE EGYPTIAN LIVING ROOM: THE INFLUENCE
OF ADOPTING WIDESCREEN TELEVISION SETS ON EGYPTIAN AUDIENCE'S
VIEWING PRACTICE
}

\begin{abstract}
Widescreen television sets represent today a large share of the home television viewing market in Egypt with more viewers adopting them everyday and discarding their old traditional televisions. This study, therefore, investigates the rising adoption of widescreen televisions in Egypt and its influence on audience's viewing practice, attitude and enjoyment of viewing. The study covers such areas of knowledge as characteristics of widescreen televisions, media consumption, attention and social contexts within the frame of widescreen television viewing. To complement the data gathered through the literature review, the empirical phase of the study employed an interview data collection technique. Interviews with 16 Egyptian viewers who watch widescreen televisions at their homes were held.

The findings of both the literature review and the interviews suggested that widescreen televisions could make a significant change in the Egyptian home television viewing practice. Greater audience's attention and absorption of programmes content were revealed when watching widescreen televisions. The findings indicated also that widescreen televisions could have more technical and social uses in the life of Egyptian audience than their preceding traditional television sets.
\end{abstract}

\section{Research context}

Year after year, with the continuous advances in digital technology as well as screen technology, new television formats are introduced, set sizes increase and the prices of television sets decline. For example, and since 2004, sales of digital 16:9 widescreen televisions worldwide has increased dramatically (Abowd, 2007; Kanellos, 2010). In Egypt, and similar to the rest of the world, widescreen television sets have come into broad use. The Egyptian consumer electronics industry is taking in millions of pounds in profits selling widescreen digital televisions, and this volume will certainly increase over the next few years as the full DTV transition date approaches. Widescreen televisions coupled with digital reception represent a significant change from the past in how television programs are delivered to the Egyptian viewer. A fan can enjoy the game as if he was sitting in a luxury box at the stadium. All the visual and auditory excitement is provided. Moreover, the widescreen television has an obvious similarity to the movie screen found in movie theaters. This feature is particularly important for those viewers of movies in the home who try to replicate the theater experience. A film shot in a widescreen aspect ratio has a much greater impact if it is displayed on a widescreen in that same aspect ratio.

\section{Research significance}

With that growing segment of television audience worldwide watching programming through large widescreen televisions, there is a serious need to include both the two variables of screen size and aspect ratio in the academic literature in order to further understand the role of media impact on viewers. In the past, research has been done to assess the changes in the television viewing process brought on through various television-related technologies such as VCRs (e.g., Johnson, 1989) and digital video recorders "DVRs" (e.g., Smith, 2005). However, similar research focused on the changes in media consumption brought on by the increasing presence of widescreen televisions cannot be found. Studying the impact of widescreen televisions as a new distinct television innovation is, therefore, an important contribution to the media consumption literature as well as the broader study of television. This could help us better understand different reasons for adopting widescreen televisions and to assess their uses after adoption. Thus, the focus of the present study is to examine what impact the adoption of widescreen televisions could have on the Egyptian audi- 
ence's viewing practice. The study aims also to investigate the role of television in Egyptian homes where widescreen televisions are present. Using an interview data collection technique to investigate the viewing and usage of widescreen televisions in Egyptian homes, the study will explore Egyptian viewers' perceptions and conceptualizations of this changing television environment and how it relates to viewing.

\section{Specifications of television screens and their effects on viewer's attention}

Historically, many researchers have emphasized the role of attention to different programs' content as an important inquiry (e.g., Reeves et al, 1985; Krugman and Johnson, 1991; Krugman et al, 1995). They observed audiences' actual attention to the content presented on the screens in front of them, and the physiological and emotional impact of the content on viewers. On the other hand, fewer researchers conducted research on the specifications of the screens themselves and the technical nature of the physical television sets. Lombard (1995) and Lombard et al (1997), for example, found that viewers enjoy larger screens and feel the viewing practice to be more intense and more "real;" meaning a "non-mediated experience," when watching them.

Another study found that large screens (90" picture) created greater arousal and memory in viewers than a 22" screen (Detenber and Reeves, 1996). For television images displayed in high resolution, the viewers preferred larger displays (Neuman, 1990). Reeves et al (1999) explored the effects of screen size and message content on attention as well as arousal. The researchers compared viewers' attention and arousal (between a 56" screen, a 13" screen, and a 2" screen) using physiological measures (i.e. heart rate deceleration and skin conductance).

They found the highest levels of attention and arousal for the largest screen as compared to the smaller 13" and 2" screens (Reeves et al., 1999). Consequently, it could be concluded that large widescreen televisions produce more attention, greater memory recall, greater physiologic response and more intense direct response to images on the screen.

\section{Widescreen televisions as an innovation}

As a rapidly diffusing television innovation in Egypt, widescreen television needs to be assessed according to Egyptian viewers' perceptions of innovativeness. Rogers (2003) analyzed the characteristics of an innovation as perceived by individuals using four criteria: relative advantage, compatibility, complexity and observability:

1. Relative Advantage refers to the degree that users perceive the superiority of an innovation. The perceived advantages are the most important. Greater perception of innovation superiority leads to more rapid diffusion. For widescreen televisions and its rapid adoption in Egypt, this concept suggests that Egyptian viewers are likely to perceive a great relative advantage and differentiation over their prior television experience.

2. Compatibility relates to the user's perception of consistency with prior experience and values. As television is a widely adopted home media form in Egypt, Egyptian viewers are likely to view widescreen televisions as naturally compatible with accepted social use of television.

3. Complexity refers to the difficulty of understanding and using an innovation. Innovations or ideas that are easy to understand in concept are more quickly adopted. It is relatively easy to understand the basic advantage of a widescreen television. However, the technical specifications and installation may present a level of complexity not previously encountered by Egyptian viewers.

4. Observability refers to the post-adoption variable of being openly visible to others who may also decide to adopt the innovation. Widescreen televisions are considered in Egypt as a social prestige purchase that suggests observability in how Egyptian owners talk about and include others in the enjoyment of their purchase. Observability is likely to be of large influence for potential widescreen Egyptian buyers who experience the television in friends' or neighbours' homes.

\section{Technology of widescreen television sets}

Traditional Cathode Ray Tube (CRT) television has been the television technology used since television introduction (Sterling and Kittross, 2002). CRT televisions have three very distinct characteristics:

They operate using an analog signal of radio frequency waves for transmission

Their traditional box shape has a 4:3 aspect ratio 
Their overall size is technologically limited to less than 37 diagonal inches. Major innovations have been produced on all three of these traditional CRT television characteristics with the introduction of plasma and liquid crystal display (LCD) widescreen televisions (Ostendorp et al, 2005).

Plasma and LCD technologies allowed the production of thin flat 16:9 widescreen televisions larger than 40 diagonal inches.

Moreover, while CRT televisions display 583 pixelated lines (625 in theory), which are referred to as "resolution," widescreen televisions display 720 or 1080 lines providing sharper images. Widescreen televisions use either an interlace scan for projecting lines (e.g., 720i and 1080i) onto the screen or a progressive scan (e.g., $720 \mathrm{p}$ and 1080p). The progressive scan is the most advanced technology placing all the lines onto the screen simultaneously and used with both DTV and HDTV (Ostendorp et al, 2005; Silva, 2011).

The table below shows some of the most used terms in today's world of widescreen televisions (Lewis, 2007; DTV Shopping Guide, 2011).

\section{Term \\ Analog TV \\ Digital TV \\ (DTV)}

\section{Standard Definition TV (SDTV)}

\section{Enhanced Definition TV (EDTV)}

\section{DTV Tuner}

(decoder or set-top box)

\section{Integrated DTV}

\section{High-Definition Television (HDTV)}

\section{HDTV Monitor \\ (HDTV Ready) \\ Aspect Ratio}

\section{Definition \\ Today's TV system using radio frequency waves to transmit and display pictures and sound. 625 interlaced (625i) is the resolution of analog PAL TV. \\ Television delivered and displayed using radio frequency waves which contain information that is digitally encoded for improved quality and efficiency. \\ Basic digital television transmission that may be displayed with 625 progressively scanned lines (625p) in $16 \times 9$ or $4 \times 3$ format.}

A Better digital television transmission than SDTV with $625 \mathrm{p}$, in a $16 \times 9$ or $4 \times 3$ display and Dolby digital surround sound. 625p is the quality used by most DVD players.

A device capable of receiving and outputting DTV signals for display. May be stand-alone or integrated in the set.

A DTV that has the digital tuner built into the set. It does not need a separate set-top box to receive over-the-air DTV signals.

The best quality digital picture, widescreen $(16 \mathrm{x}$ 9 ) display with at least 720 progressively scanned lines (720p) or 1080 interlaced lines (1080i) and Dolby digital surround sound.

A television set that can display HDTV programming. $4 \mathrm{X} 3$ - Traditional TV aspect ratio, that is, the screen's width as compared to its height.

$16 \mathrm{X} 9$ - Widescreen TV aspect ratio that is more like a movie screen than a traditional TV.

Programs could be provided to widescreen televisions either in high-definition format, which is natively $16 \times 9$, or as an anamorphically-compressed standard definition 4 x 3 picture. 
Flat Panels

Front Projector
Liquid Crystal Display (LCD) and Plasma

televisions are flat panel technologies used to produce widescreen televisions. Historically, the

Plasma television has been the principal technology for widescreens. LCD screens have been associated with the smaller television sizes in the past but continue to expand in size reaching up to 60 -inches.

For theater-like experience, front projectors are not technically televisions. They need a dark room and complex set-up. Front projectors are very expensive and can create very large viewing areas that surpass sizes currently available in Plasma or LCD televisions. The front projector market is divided into four use categories: home theater, portable, education, conference room.

\section{Widescreen televisions and viewers' feeling of presence}

The concept of "presence" is that viewers become absorbed and engaged in the mediated content such that they feel like they are at the event or that the programming is compellingly realistic. Presence during watching television means that the viewer feels and acts like he or she is having a non-mediated experience. The viewer therefore is responding "directly" to objects, events, and people in that environment rather than "indirectly" to what seem to be only symbolic representations or recreations of objects, events, and people that are in fact somewhere else (Lombard et al., 1997). Widescreen televisions accentuate that absorbing quality becoming a new variable of "presence" in the home. They offer a more transparent medium for connection to televised experiences such that the idea of mediation is forgotten by the viewer. Therefore, with widescreen televisions, viewers have an increased opportunity to participate in events and society in more personally compelling detail via pixel-enriched sensory panels.

\section{Household centrality and social role of widescreen televisions}

Comstock and Paik (1991) were the first two researchers to introduce the concept of "household centrality of television." This concept describes the impact of television on family and social life and also the sociological functions of television in the home. ${ }^{(1)}$ In Egypt, when television emerged as the focus for Egyptian family in-home leisure in the 1960s, it replaced other fixtures in the home that had previously represented family unity and happiness. Indeed, the rise of television's prominence within Egyptian homes cannot be solely attributed to the commercial interests that so effectively built, promoted, and sold the sets. The quick diffusion of television at that time and the rapid arrival of such an engaging and time-consuming device within the reach of the average home strongly suggest that television played, and is still playing, a crucial social role in Egyptian society (Spigel, 1992).

Today, the increasing adoption of widescreen televisions in Egypt recalls again the idea of television's role in Egyptian society and in individuals' lives. Much like the early era of television in Egypt during the 1960s, widescreen television sets now possess the same novelty and social prestige factor. As such, widescreen televisions have the potential to alter the social functions of television by increasing household viewing in groups "i.e., co-viewing" as well as increasing the frequency of sharing that consumption experience with others who are not living in the home (Smith, 2005). They could be the vehicle for increased social viewing practices with families, friends, colleagues, and neighbors. The most prominent social uses include watching movies and live sporting events with family and friends (Morrison and Krugman, 2001). Another form of family and friends participation using widescreen televisions, which does not include "viewing" as used in the classic sense, is that widescreen televisions could really facilitate multi-player video gaming as an activity where participants competed against each other as well as gathered to watch others compete. These games particularly are suited to be used with widescreen televisions (Morrison and Krugman, 2001). 


\section{Research questions}

This study examines the viewing and usage of widescreen televisions in Egyptian homes. It explores Egyptian viewers' perceptions and conceptualizations of widescreen televisions as an innovation and how that relates to the viewing process. The study's research questions are as follows:

1. How do Egyptian viewers conceptualize and perceive widescreen televisions?

2. What are the reasons, justifications and context for purchasing widescreen televisions in Egypt?

3. How are widescreen televisions used in the Egyptian home?

4. Within the Egyptian context, is 16:9 widescreen television viewing a different viewing experience from 4:3 traditional television viewing?

5. Do Egyptian viewers of widescreen televisions pay more attention to television during the programming and commercials?

6. Do Egyptian viewers of widescreen televisions feel more connected to the television content?

7. Has the presence of widescreen televisions influenced family and social viewing in Egypt?

8. What are the other technologies used in conjunction with widescreen televisions in Egypt?

\section{Method}

The study methodology involved an initial literature review which helped to gain context and insight into widescreen televisions, and their viewers' attitudes and motivations. Using the information gained via the literature review, a small scale interview instrument was formulated and conducted with a sample of Egyptian viewers who own or watch widescreen televisions at their homes. The interview method explored the related issues of widescreen television viewing, effects and uses in the Egyptian context. It was rather successful to assess what changes widescreen televisions brought to the home media environment in Egypt, and the influence of adopting widescreen televisions on Egyptian audience's viewing practice. Johnson (1989) used a similar method in an exploratory study of the impact of VCRs on home television and movie entertainment. Johnson's study followed the basic methodological order of finding comprehension and clarification via literature review and then finishing with an empirical data gathering phase to gain confirmation.

The participants who took part in the interviews were sought through colleagues, friends, neighbors, associates, students, etc. Being a viewer of a widescreen television was, of course, a necessity for any person to join the research sample. In fact, researchers have not totally agreed over the optimal size of interviews' samples (Baker, 1999). Larger samples may have the potential of greater collective experience available for the discussion, but sometimes they may not be practical. As such, the current study used a sample of 16 participants representing diverse ages of the adult population in the Egyptian society, which gave the sample a robust cross-generational representation. Nine of the sixteen participants were male with the other seven being female. Participants varied in their marital status and wealth. However, they were all from the educated segments of the Egyptian society. Generally speaking, the interviews' sample reflects the makeup of the middle-to-upper socio-economic class in Egypt.

Multiple drafts of the questions format were carefully screened before a final version was created. Only open-ended questions were used. Open-ended questions allow for more clarification about specific issues and bring forth additional depth to the information (Stewart and Shamdasani, 1990). Eventually, a 13-question form was formulated, which assured that the length of the interview was suitable for an average participant (Please, refer to the Appendix for the interview questions and general procedures). The interview process itself lasted approximately one month. Analysis of the interviews' transcriptions afterwards employed the cut-and-paste method using suitable computer software. Relevant material from each transcript was placed in categories. Analysis was then conducted on the groupings of relevant responses for each question or topic area.

\section{Findings and discussion}

Studying widescreen-television viewing, its effects and uses in Egyptian homes, and how Egyptian viewers conceptualize widescreen televisions and respond to them were the two main aims of this study. The study employed, therefore, a robust research design, including a comprehensive literature review and an interview data collection technique, to achieve its aims and answer its questions. Answering each research question in full has contributed to the understanding of the study's subject. The study's findings, generated through both the literature review and the interviews, follow: 
- Generally speaking, the participants reported only the valuable benefits of widescreen-television viewing practice and uses at home. There were no reports of dissatisfaction. Widescreen televisions were valued by the participants for their supporting role in delivering higher quality content.

- The interviews revealed that there are clear and obvious advantages to widescreen televisions over their predecessors. The widescreen television itself portrays its immediate advantage; many participants reported that their basic enjoyment had increased due to the presence of the widescreen television in their homes.

- The wide 16:9 aspect ratio of the screen was appreciated by the participants as the most significant feature of widescreen televisions.

- Participants reported significant experiential differences in widescreen television viewing over traditional television viewing. The widescreen television viewing experience was found to be more enjoyable, easy to watch, and to approximate a theater-like atmosphere. Life-like picture and compelling sound help viewers feel like they were being transported to the location of the content.

- Many participants confirmed that their adoption of widescreen televisions had increased the amount of television they watch daily and their appreciation and use of the technology.

- Many participants mentioned digital broadcasting when talking about their widescreen televisions. Perhaps this is because digital signals are going to replace analog ones in Egypt by government authorization in the near future. The upgrade in signal technology from analog to digital signals was found to occur at several participants' viewing locations. Participants were most willing to admire the benefits of digital programming. Digital broadcasting was also regarded by many of them as a main reason to upgrade their televisions.

- Major uses of widescreen televisions given by the participants were watching TV programming and movies, playing video games, watching sports events, and hosting social occasions. On the other hand, minor uses of widescreen televisions given by the participants included listening to music, using them as a computer screen or Internet portal, as furniture and for aesthetic purposes, and as a baby-sitter.

- Most participants cited watching movies as the principal use for the widescreen television and noted the enhanced movie experience facilitated by the wide format. Participants mentioned the ability of the widescreen television to deliver "the experience" most associated with movie theatre-viewing.

- Gaming devices and DVD players were often mentioned within participants' answers as other technologies that could be used with the widescreen television at home. Other functions of mixing computer capabilities with the television technology were mentioned as well. High use of the Internet at home and during television viewing was also mentioned in conjunction with widescreen viewing. As such, it could be said that Egyptian viewers of widescreen televisions are heavy consumers of home technologies across the spectrum of the television, computer, and gaming technology.

- With widescreen televisions, larger spaces are needed for placing the units and more visual distance is needed for optimal viewing (Ramsay, 2011). Viewing widescreen televisions at distances less than the recommended distances could create visual blurring to the viewer. For most of the participants, however, the widescreen television has been placed exactly where the previous television was placed. None of the participants made architectural adjustments to their homes in order to accommodate the widescreen television.

- All participants reported that widescreen televisions are better able to hold their attention than previous traditional televisions. Many of them reported that attention levels for programming in general were high with the widescreen television. However, the participants reported less attention to commercials than programming.

- Many participants mentioned high levels of being absorbed and engaged when watching programming with widescreen televisions, which denotes connection and a more intense television consumption practice. The interviews indicated that widescreen televisions significantly absorb viewer's attention better than traditional televisions and create a sense of "presence." The participants also used terms like "realistic" and "life-like" to explain their viewing experience with widescreen televisions. It appears that widescreen televisions can connect Egyptian viewers to electronic content in a compelling and focused way.

- The interviews' results support the literature review's finding that widescreen televisions are themselves a kind of attraction to encourage co-viewing. Actually, widescreen televisions make viewing more available and comfortable for more than one person. The technology itself allows greater flexibility 
for group viewing. Many participants stated that co-viewing in general had increased. Such results could be an indication that family/co-viewing patterns in the Egyptian home may change with the presence of widescreen televisions. The interviews' results indicated also that widescreen televisions could increase programming, event, and movie viewing with people from outside the home. Only less than half of the participants said that they were not willing to engage in more social viewing due to the adoption of the widescreen television, citing no disposition to do so prior to or after the adoption.

\section{Conclusions}

Widescreen televisions represent an important historic shift in the television industry in Egypt and worldwide with more viewers adopting them everyday and discarding their old traditional television sets. However, it is really difficult to find a reliable research study exploring how Egyptian viewers conceptualize such a television technology. The present study, therefore, tried to examine the adoption and use of widescreen televisions in Egypt from the perspective of the way Egyptian people consume television. It attempted to examine the changes and impact that widescreen televisions could bring to the home television viewing environment in Egypt. The literature review phase of the study was focused on four general areas: 1) conceptualization of widescreen television by users, 2) viewing and using of widescreen televisions as an innovation, 3) screen size, attention and presence, and 4) household centrality of television.

Some interviews were used afterwards to generate original data from the Egyptian viewers of widescreen televisions. The interviews' results complemented the data collected through the literature review phase of the research. In brief, the interviews were able to prove that widescreen televisions, within the Egyptian context, could provide more enjoyment, ease of watching, a theater-like atmosphere in a comfortable home setting, and a more life-like picture and compelling sound that makes viewers feel closer to the events presented on screen.

The Egyptian viewers of widescreen televisions were found to pay greater attention levels to the television screen. They were also found to watch more programming and more movies, and to play more video games than those viewers who watch traditional televisions. Moreover, the enhanced viewing experience of widescreen televisions was found to be shared on many occasions with others in the home (i.e., internal social function,) and sometimes with friends and visitors (i.e., external social function).

\section{Study's limitations and areas of future research}

This study asked Egyptian viewers how they think about their widescreen televisions and the influence of such new televisions on their viewing practices. The study used a sample of only 16 persons. As such, the most critical limitation of this study could be the strength of the sample size. Employing larger sample sizes in future studies could produce more significant results. Second, the participants of the interviews were recruited via a convenience sampling technique. The participants were also over-representing the average education levels from the general Egyptian population of widescreen television viewers. The conclusions reached, therefore, may not be easily generalised to the whole population of Egyptian viewers. Hence, more research is needed to determine the effects of widescreen television adoption in other segments of Egyptian society. Such research may be better administered using in-home observation techniques besides conducting in-depth interviews with more specific and intensive questions. There is also a need for a study that addresses the related issue of widescreen television use in public spaces.

\section{Acknowledgements}

The researcher would like to thank all those who took part in the study's interviews for their time and efforts. Their help is really appreciated.

\section{Notes}

\section{Endnotes}

1. Some other researchers prefer to use the term "household TV orientation" which refers to "the degree to which TV plays a central role in the home" (Roberts et al., 2005). 


\section{References}

\section{References}

Abowd, R. (2007): Flat panel display market research-World. New York: Pacific Media Associates.

Baker, T. L. (1999): Doing social research (3 ${ }^{\text {rd }}$ ed.). Boston: McGraw-Hill College.

Comstock, G. A., and Paik, H. J. (1991): Television and the American child. San Diego: Academic Press.

Detenber, B. H., and Reeves, B. (1996): 'A bio-informational theory of emotion: Motion and image size effects on viewers.' Journal of Communication. 46(3): 66 .

Johnson, K. F. (1989): An investigation of the VCR viewing environment. Unpublished Dissertation, University of Georgia, Athens.

Kanellos, M. (2010): Sales of LCD TVs Going Like Crazy. URL:

http://news.com.com/Sales+of+LCD+TVs+going+like+crazy/2100-1041_3-6076240.html

Krugman, D. M., and Johnson, K. F. (1991): 'Differences in the consumption of traditional broadcast and VCR movie rentals.' Journal of Broadcasting \& Electronic Media. 35(2): 213.

Krugman, D. M., Cameron, G. T., and White, C. M. (1995): 'Visual attention to programming and commercials: The use of in-home observations.' Journal of Advertising, 24(1): 1.

Lewis, D. M. (2007): Front Projection for Home Theater. URL:

http://www.allht.com/article/print.php?id=2

Lombard, M. (1995): 'Direct responses to people on the screen: Television and personal space.' Communication Research. 22(3): 288.

Lombard, M., Ditton, T. B., Grabe, M. E., and Reich, R. D. (1997): 'The role of screen size in viewer responses to television fare.' Communication Reports. 10(1): 95-106.

Morrison, M., and Krugman, D. M. (2001): 'A look at mass and computer mediated technologies: Understanding the roles of television and computers in the home.' Journal of Broadcasting 85 Electronic Media. 45(1): 135 .

Neuman, W. R. (1990): Beyond HDTV: Exploring subjective responses to very high definition television. A research report for GTE Labs and the TVOT Consortium. Cambridge: MIT.

Ostendorp, P., Foster, S., and Calwell, C. (2005): 'Televisions: Active mode energy use and opportunities for energy savings.' Journal of Media Communication. (April 4, 2007).

Ramsay, R. (2011): 10 things to know before buying a big screen TV. URL: http://asia.cnet.com/reviews/home_av/tvs/0,390 1,00.htm

Reeves, B., Lang, A., Kim, E. Y., and Tatar, D. (1999): 'The effects of screen size and message content on attention and arousal.' Media Psychology. 1(1): 49.

Reeves, B., Thorson, E., and Schleuder, J. (1985): 'Attention to television: Psychological theories and chronometric measures.' In: J. Bryant and D. Zillmann (Eds.): Perspectives on media effects. Hillsdale, N.J.: L. Erlbaum Associates.

Rogers, E. M. (2003): Diffusion of innovations (5th ed.). New York: Free Press.

Silva, R. (2011): Wide-screen TV: the 16:9 Factor. URL

http://hometheater.about.com/cs/television/a/16x9tvfactor_2.htm

Smith, S. M. (2005): From viewers to decision-makers: The impact of digital-video recorders on household media consumption. Unpublished Dissertation, University of Georgia, Athens.

Spigel, L. (1992): Make room for TV : television and the family ideal in postwar America. Chicago: University of Chicago Press. 
Sterling, C. H., and Kittross, J. M. (2002): Stay tuned: a history of American broadcasting (3 ${ }^{\text {rd }}$ ed.). Mahwah, N.J.: Lawrence Erlbaum Associates.

Stewart, D. W., and Shamdasani, P. N. (1990): Focus groups : theory and practice. Newbury Park, Calif.: Sage Publications.

\section{Appendix: Interview's questions and general procedures}

1. Introduction

2. Explaining the purpose of the interview

3. Introducing interview's rules

4. Demographic questions

(a) Each participant is asked to give some data about his/her age, education, family, work situation, etc., and to explain how television is a part of his/her life.

5. Interview open-ended questions

(a) What, in your opinion, is the widescreen television?

(b) Why is the widescreen television so appealing to you?

(c) What were your reasons and motivations for purchasing a widescreen television?

(d) What is the role of television in your home? And did that role change with the adoption of the widescreen television?

(e) In what ways (beyond the obvious viewing of television programming) is the widescreen television used in your home?

(f) Do you find the widescreen television more engaging and easier to connect you to the programming?

(g) How much attention do you pay to the screen of the widescreen television as compared to your previous traditional television?

(h) Since your adoption of the widescreen television, has your television viewing habits changed? If so, how?

(i) Since your adoption of the widescreen television, have you increased or decreased your amount of television viewing?

(j) What types of programs do you watch more now because you have a widescreen television?

(k) Has the presence of the widescreen television impacted your family life in any way?

(l) Compared to your previous television viewing habits, do more members of your family watch the widescreen television together?

(m) Are other people outside of your family invited over to view/participate in any activity associated with television? Does this type of social activity occur more, less or the same since your adoption of the widescreen television?

6. Thanking the participants for their assistance.

\section{Author Information}

Mustafa Mahmoud YOUSRY, PhD, is Associate Professor and researcher at the Department of Photography, Cinema, and Television, Faculty of Applied Arts at Helwan University, Dokki, Giza, Egypt. 